\title{
Disposition Kinetics of Cefepime in Healthy and Experimentally Salmonella Typhimurium Infected Broiler Chicken
}

\author{
Taha A. Attia ${ }^{1}$, Hanan A. Azoz ${ }^{2 *}$,Mohamed H. Shamakh² \\ ${ }^{1}$ Department of Pharmacology, Faculty of Veterinary Medicine, University of Sadat City, \\ ${ }^{2}$ Biochemistry, Toxicology and Feed Deficiency Department "Pharmacology Unit", Animal \\ Health Research Institute, Dokki, Egypt.
}

\section{Abstract}

Cefepime is a broad-spectrum semi synthetic $\beta$-lactamase resistant fourth generation cephalosporin. Looking to potential for clinical use, pharmacokinetics of cefepime following single intravenous and intramuscular (IM) dose (100mg/kg b. wt.) in healthy and experimentally Salmonella typhimurium infected broiler chickens were determined. Cefepime concentration in serum samples was determined by reverse-phase high performance liquid chromatography with mobile phase. The mobile phase was a mixture of $10 \mathrm{mM}$ phosphate buffer ( $\mathrm{pH} 7$ ): Methanol; 75:25 was always freshly prepared. Flow rates were $1 \mathrm{ml} / \mathrm{min}$. UV detection was performed at $256 \mathrm{~nm}$, injection volume was $20 \mu \mathrm{l}$. After a single intravenous injection, cefepime reached its maximum serum concentrations of $4.28 \pm 0.37 \mu \mathrm{g} / \mathrm{ml}$ in normal chickens, while in the infected chickens, the maximum serum concentration was $2.62 \pm 0.72 \mu \mathrm{g} / \mathrm{ml}$. Cefepime was eliminated after intravenous injection with half-life $\left(\mathrm{t}_{1 / 2 \beta}\right)$ of $4.608 \pm 0.145 \mathrm{~h}$ in normal which significantly longer than $4.19 \pm 0.158$ $\mathrm{h}$ in infected chickens. The mean residence time (MRT) was $6.51 \pm 0.189 \mathrm{~h}$ in normal vs $5.86 \pm 0.18 \mathrm{~h}$ in infected chickens. After IM administration the drug reached its maximum serum concentrations of $193.06 \pm 2.27 \mu \mathrm{g} / \mathrm{ml}$ at maximum time of $1.138 \pm 0.012 \mathrm{~h}$ in normal, while in infected chickens the maximum serum concentrations was $132.93 \pm 1.53 \mu \mathrm{g} / \mathrm{ml}$ attained at maximum time of $1.265 \pm 0.013$ $\mathrm{h}$. In conclusion a cefepime at dose of $100 \mathrm{mg} / \mathrm{kg}$ administered intravenously or IM at $24 \mathrm{~h}$ intervals may provide successful treatment of chicken infected with Salmonella typhimurium.

Keywords: Cefepime, Salmonella typhimurium, High performance liquid chromatography, Broiler chicken.

Received: May 30, 2018 Accepted: June 21, 2018 Published: June 30, 2018

*Corresponding Author: Hanan A. Azoz E-mail: Hanan.a.azoz@hotmail.com

Citation: Attia et. al., 2018. Disposition kinetics of cefepime in healthy and experimentally Salmonella typhimurium infected broiler chicken. SVU-IJVS, 1 (1): 66-81.

Copyright: This is an open access article distributed under the terms of the creative common attribution license, which permits unrestricted use, distribution and reproduction in any medium provided the original author and source are created.

Competing interest: The authors have declared that no competing interest exists. 


\section{Introduction}

Cephalosporins are among the most widely used group of antibacterial in veterinary and human medical practice. Cefepime, a new fourth generation cephalosporin, with a modified zwitterionic structure that allows more favorable penetration into the bacterial cells, higher affinity for its molecular target (PBP3) and reduced susceptibility to $\beta$-lactamases (Del et al., 2008). Cefepime is unique because of its broad spectrum of activity that includes gram-positive cocci, enteric gram-negative bacilli and Pseudomonas (Sultana and Arayne, 2007, Ozbek and Otuk, 2010). It has advantage of activity against some Extended-spectrum $\beta$-lactamase (ESBL)producing strains of Klebsiella and E. coli that have become resistant to many other $\beta$ lactam drugs and fluoroquinolones (Riviere and Papich, 2009). In view of the species variation in the disposition kinetic data of antimicrobials, it is considered important to investigate the disposition kinetics of drugs in different animal species and under different environmental conditions. cefepime have been described in various animals species as in rabbits (Abd EL-Aty et al., 2007, Rule et al.,2010), rats and monkeys (Forgue et al., 1987,Klesel and seeger 1983 ), Foals and dogs (Gardner and Papich 2001), buffalo calves (Joshi and Sharma 2007, Joshi and Sharma 2009 ), cow calves (Patel et al.,2006,Patil et al.,2012), goats (EL-Rabbat et al.,2010), sheep(Patel et al.,2010) and horses (Guglick et al.,1998). Currently, there are no available data on the pharmacokinetics of cefepime in broiler chickens.

Salmonella typhimurium (S. typhimurium) is a pathogenic Gram-negative bacterium predominately found in the intestinal lumen. Salmonellosis among domestic animals may range from latent (in-apparent) to severe and fatal, the latter especially in young animals. Symptoms vary but usually include weakness, prostration, fever, and diarrhea. Pregnant animals may abort. Convulsions may occur in cattle. Salmonella typhimurium causes disease in horses, cattle, sheep, and chickens (Ryan et al., 2013) .

The aim of this study is to describe the pharmacokinetic behaviour of cefepime in serum of healthy and experimentally infected broiler chickens with Salmonella typhimurium after single intravenous (IV) and intramuscular (IM) administration.

\section{Materials and methods Materials}

1- Drug: Cefepime hydrochloride powder (Maxipime ${ }^{\circledR} 1 \mathrm{~g}, \quad(10 \%) \quad$ Bristol-Myers Squibb, New York, NY, USA) was reconstituted with sterile pyrogen free water to yield a final concentration of $10 \%$ according to the manufacturer's guidelines. Cefepime hydrochloride (purity $\geq 98.0 \%$ ) was purchased from Sigma (3050 Spruce Street, Saint Louis, MO 63103, USA). The chemical structure of Cefepime hydrochloride is as follows:

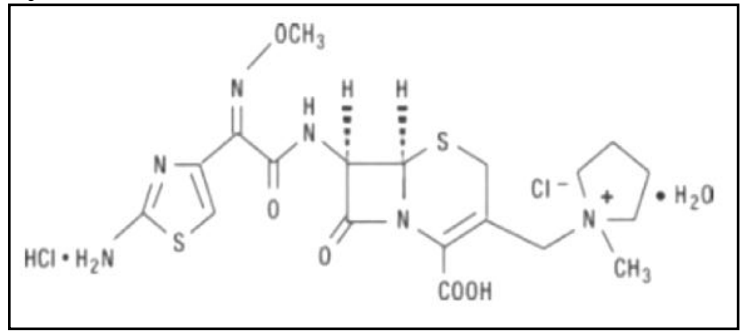

Fig. 1. Chemical structure of Cefepime "Maxipime" (Endimiani et al., 2008)

2- Chickens: This study was conducted on 24 apparently normal Salmonella typhimurium free white leghorn broiler chickens of $1.5 \pm 0.2 \mathrm{~kg}$ (35 days age). All chickens were obtained from El-Arabia poultry breeding farm. They were divided into 4 groups, were housed in plastic cages. Chickens were fed on balanced drug free ration for two weeks to ensure complete excretion of any drugs from their bodies. Water was supplied ad-libitum. Chickens 
were injected with cefepime at dose 100 $\mathrm{mg} / \mathrm{kg} \mathrm{b}$.wt according to (Feizi et al., 2009).
3-Experminetal design: Chickens were grouped into 4 groups (each group 6 chickens) as shown in Table 1.

Table 1. Treatment protocol.

\begin{tabular}{|c|c|l|}
\hline Groups & No./group & \multicolumn{1}{c|}{ Group and Treatment } \\
\hline Gr1 & 6 & $\begin{array}{l}\text { Apparently normal chickens were injected intravenously (IV) } \\
\text { with a single dose of } 100 \mathrm{mg} / \mathrm{kg} . \mathrm{b} \text {. w. into the right-wing vein. }\end{array}$ \\
\hline Gr2 & 6 & $\begin{array}{l}\text { Apparently normal chickens were injected intramuscularly (IM) } \\
\text { with a single dose of } 100 \mathrm{mg} / \mathrm{kg} . \mathrm{b} \text {. w. into the thigh muscle. }\end{array}$ \\
\hline Gr3 & 6 & $\begin{array}{l}\text { Experimentally Salmonella typhimurium infected chickens were } \\
\text { injected IV with a single dose of } 100 \mathrm{mg} / \mathrm{kg} \text {. b. w. into the } \\
\text { right-wing vein after appearance of clinical symptoms. }\end{array}$ \\
\hline $\begin{array}{l}\text { Experimentally Salmonella typhimurium infected chickens were } \\
\text { injected IM with a single dose of } 100 \mathrm{mg} / \mathrm{kg} \text {. b. w. into the the } \\
\text { thigh muscle after appearance of clinical symptoms. }\end{array}$ \\
\hline
\end{tabular}

4-Salmonella typhimurium strain: Salmonella typhimurium strain of poultry origin obtained from poultry department, Animal Health Research Institute, Dokki, Giza, Egypt is used for experimental infection. Clinical signs (ruffled feathers, diarrhea, loss of appetite and thirst) were appear after given an oral inoculation with $10^{12}$ live $S$. typhimurium (Wendy et al., 1998) and transferred to a pen $\left(1.5 \mathrm{~m}^{2}\right)$ of fresh litter in an isolation room.

5- Samples: Blood samples (0.5 to 1 $\mathrm{ml} / \mathrm{sample}$ ) were collected from the leftwing vein of each chicken into clean test tubes at zero time (0) prior to injection and then, at 5,10,15, and 30 minutes and 1, 2, 4, 8, 10, 12 and 24 hours after injection. All blood samples were centrifuged at 3500 rpm for 10 minutes, and sera were harvested and stored frozen at $-20{ }^{\circ} \mathrm{C}$ until analyzed for cefepime.

\section{Methods}

Cefepime was extracted from serum according to the method described by (Dog $־$ An et al., 2013). The concentration of cefepime was determined by high performance liquid chromatography (HPLC) according to (Jimenez Palacios et al., 2005). An aliquot of $500 \mu \mathrm{L}$ of chicken serum was added in an epindorf tube, then total volume was completed to $1 \mathrm{~mL}$ with addition of $10 \%$ TCA. After centrifugation at 6,000 rpm for $5 \mathrm{~min}$, supernatants were filtrated with $0.45 \mu \mathrm{m}$ and transferred into the autosampler vial for analysis.

\section{Reagents and Solvents:}

All reagents were of analytical grade. Methanol was of HPLC grade. Sodium dihydrogen phosphate and dibasic sodium phosphate were obtained from Merck (Barcelona, Spain). Deionized water was used.

\section{Instrument and Analytical Conditions:}

Agilent series 1200 quaternary gradient pump, series 1200 autosampler, series 1200 UV Vis detector, eclipse XDB C18 column $(5 \mu \mathrm{m}, 4.6 \mathrm{~mm}, 250 \mathrm{~mm})$. The mobile phase consisted of $10 \mathrm{mM}$ phosphate buffer $(\mathrm{pH}$ 7): Methanol; 75:25 was always freshly prepared. Flow rates were $1 \mathrm{ml} / \mathrm{min}$. UV 
detection was performed at $256 \mathrm{~nm}$, injection volume was $20 \mu 1$.

Preparation of standard curves of cefepime in serum:

A stock solution $1000 \mu \mathrm{g} / \mathrm{ml}$ of cefepime in deionized water was prepared. All stock solutions were stored at $+4^{0} \mathrm{C}$. Working solutions of cefepime used to spike serum were prepared at $10.00,1.00$ and $0.10 \mu \mathrm{g} / \mathrm{ml}$ concentrations from stock solutions by diluting with deionized water. Standard concentrations were obtained by further dilution in drug free normal chicken serum to obtain concentrations $0.18,1,5,10,25$, 50,75 , and $100 \mu \mathrm{g} / \mathrm{ml}$ for establishment of standard curve of cefepime according to (Dog־An et al., 2013). Cefepime was assayed in serum by the HPLC assay as previously mentioned.

\section{Pharmacokinetic analysis:}

The pharmacokinetic parameters were calculated by PK Solver: An add-in program for Microsoft Excel, version 2 (Zhang et al., 2010).

\section{Statistical Analysis:}

The data were calculated as mean \pm standard deviation. All statistical analysis was carried out according to (Berly and Lindgren، 1990) using Student's (t) probability test to express the differences between healthy and infected groups.

\section{Results}

The different concentrations $0.18,1.00$, $5.00,10.00,25.00,50.00,75.00$, and 100.00 $\mu \mathrm{g} / \mathrm{ml}$ of cefepime in antibiotic free chicken's serum and the retention time are presented in (Table 2, Fig. 2, and Fig. 3).

Recovery: The percentage recovery of cefepime spiked serum samples ranged from 96-98 \%. Retention time: The retention time of cefepime from serum was $1.666 \mathrm{~min}$.

Table 2. Area under the curve (AUC) corresponding to cefepime concentration $(\mu \mathrm{g} / \mathrm{ml})$ in spiked serum of chickens.

\begin{tabular}{|c|c|c|}
\hline Level & AUC & Conc. $(\boldsymbol{\mu g} / \mathbf{m l})$ \\
\hline $\mathbf{1}$ & 7.67 & 0.18 \\
\hline $\mathbf{2}$ & 42.62 & 1.00 \\
\hline $\mathbf{3}$ & 213.10 & 5.00 \\
\hline $\mathbf{4}$ & 426.20 & 10.00 \\
\hline $\mathbf{5}$ & 1165.50 & 25.00 \\
\hline $\mathbf{6}$ & 2491.20 & 50.00 \\
\hline $\mathbf{7}$ & 3736.80 & 75.00 \\
\hline $\mathbf{8}$ & 4982.40 & 100.00 \\
\hline
\end{tabular}

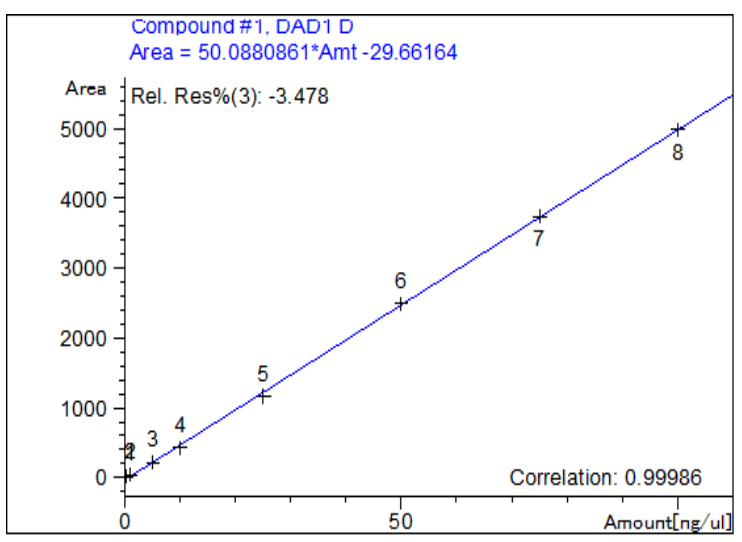

Fig. 2. Standard curve of cefepime in antibiotic free chicken serum (Data are presented as mean values). 
Table 3. Mean pharmacokinetic parameters of cefepime in healthy and Salmonella typhimurium experimentally infected chickens after single I/V injection of $100 \mathrm{mg} / \mathrm{kg} \mathrm{b}$. wt.

\begin{tabular}{|c|c|c|c|}
\hline \multirow{2}{*}{$\begin{array}{c}\text { Kinetic } \\
\text { parameters }\end{array}$} & \multirow{2}{*}{ unit } & \multicolumn{2}{|c|}{ Determinants (Mean \pm S.E., $n=6$ ) } \\
\hline & & I/V healthy & I/V infected \\
\hline $\mathrm{A}$ & $\mu \mathrm{g} / \mathrm{ml}$ & $76.5 \pm 3.65$ & $62.87 \pm 5.47$ \\
\hline$\alpha$ & $\mathrm{h}^{-1}$ & $3.26 \pm 0.50$ & $2.47 \pm 1.03$ \\
\hline $\mathrm{B}$ & $\mu \mathrm{g} / \mathrm{ml}$ & $163.59 \pm 4.39$ & $135.29 \pm 5.55$ \\
\hline$\beta$ & $\mathrm{h}^{-1}$ & $0.151 \pm 0.005$ & $0.166 \pm 0.006$ \\
\hline $\mathrm{k}_{10}$ & $\mathrm{~h}^{-1}$ & $0.216 \pm 0.007$ & $0.234 \pm 0.01$ \\
\hline $\mathrm{K}_{12}$ & $\mathrm{~h}^{-1}$ & $0.922 \pm 0.123$ & $0.664 \pm 0.342$ \\
\hline $\mathrm{K}_{21}$ & $\mathrm{~h}^{-1}$ & $2.278 \pm 0.378$ & $1.74 \pm 0.69$ \\
\hline$t_{1 / 2 \alpha}$ & $\mathrm{H}$ & $0.217 \pm 0.036$ & $0.310 \pm 0.089^{*}$ \\
\hline $\mathrm{t}_{1 / 2 \beta}$ & $\mathrm{H}$ & $4.608 \pm 0.145$ & $4.19 \pm 0.158 * * *$ \\
\hline $\mathrm{C}^{0}$ & $\mu \mathrm{g} / \mathrm{ml}$ & $240.08 \pm 3.626$ & $198.15 \pm 7.89 * * *$ \\
\hline $\mathrm{V}_{1}$ & $(\mathrm{mg} / \mathrm{kg}) /(\mu \mathrm{g} / \mathrm{ml})$ & $0.417 \pm 0.006$ & $0.505 \pm 0.019 * * *$ \\
\hline $\mathrm{CL}$ & $(\mathrm{mg} / \mathrm{kg}) /(\mu \mathrm{g} / \mathrm{ml}) / \mathrm{h}$ & $0.090 \pm 0.002$ & $0.118 \pm 0.002 * * *$ \\
\hline $\mathrm{V}_{2}$ & $(\mathrm{mg} / \mathrm{kg}) /(\mu \mathrm{g} / \mathrm{ml})$ & $0.169 \pm 0.009$ & $0.188 \pm 0.015^{*}$ \\
\hline $\mathrm{CL}_{2}$ & $(\mathrm{mg} / \mathrm{kg}) /(\mu \mathrm{g} / \mathrm{ml}) / \mathrm{h}$ & $0.384 \pm 0.048$ & $0.330 \pm 0.150$ \\
\hline $\mathrm{AUC}_{0-\mathrm{t}}$ & $\mu \mathrm{g} / \mathrm{ml} . \mathrm{h}$ & $1081.41 \pm 20.50$ & $829.91 \pm 12.68 * * *$ \\
\hline $\mathrm{AUC}_{0 \text {-inf }}$ & $\mu \mathrm{g} / \mathrm{ml} . \mathrm{h}$ & $1110.90 \pm 23.30$ & $845.46 \pm 14.06^{* * *}$ \\
\hline AUMC & $\mu \mathrm{g} / \mathrm{ml} . \mathrm{h}^{2}$ & $7234.99 \pm 340.05$ & $4959.38 \pm 213.25 * * *$ \\
\hline MRT & $\mathrm{H}$ & $6.51 \pm 0.189$ & $5.86 \pm 0.18 * * *$ \\
\hline $\mathrm{V}_{\mathrm{dss}}$ & $\mathrm{mg} /(\mu \mathrm{g} / \mathrm{ml})$ & $0.586 \pm 0.11$ & $0.694 \pm 0.016 * * *$ \\
\hline
\end{tabular}

a Kinetic parameter as described by Zhang et al., 2010. A, zero-time intercept of the distribution slope. B, zero-time intercept of decline in serum concentration of drug. $\alpha$, distribution rate constant. $\beta$, elimination rate constant. $\mathrm{k}_{10}$, first-order elimination rate constant from central compartment. $\mathrm{k}_{12}$, rate constant for passage from central to peripheral compartment. $k_{21}$, rate constant for passage from peripheral to central compartment. $t_{1 / 2 \alpha}$, the distribution half-life.t $t_{1 / 2 \beta}$, elimination half-life. $\mathrm{C}^{0}$, plasma drug concentration at $\mathrm{t}=0$ (Immediately) following drug administration. AUC 0 -t, area under the [plasma drug concentration versus time] curve. AUC ${ }_{0-\infty}$, total area under the concentration-time curve from zero to infinity. AUMC, area under the first moment curve. MRT, mean residence time. $\mathrm{Cl}$, total body clearance. $\mathrm{CL}_{2}$, Inter-compartmental clearances. $\mathrm{V}_{1}$, apparent volume of central compartment. $\mathrm{V}_{2}$, apparent volume of peripheral compartment. Significant at* $\mathrm{P} \leq 0.05 * * \mathrm{P}$ $\leq 0.01 * * * \mathrm{P} \leq 0.001$ when compared with respective values of cefepime (IV) healthy and disease chickens. 

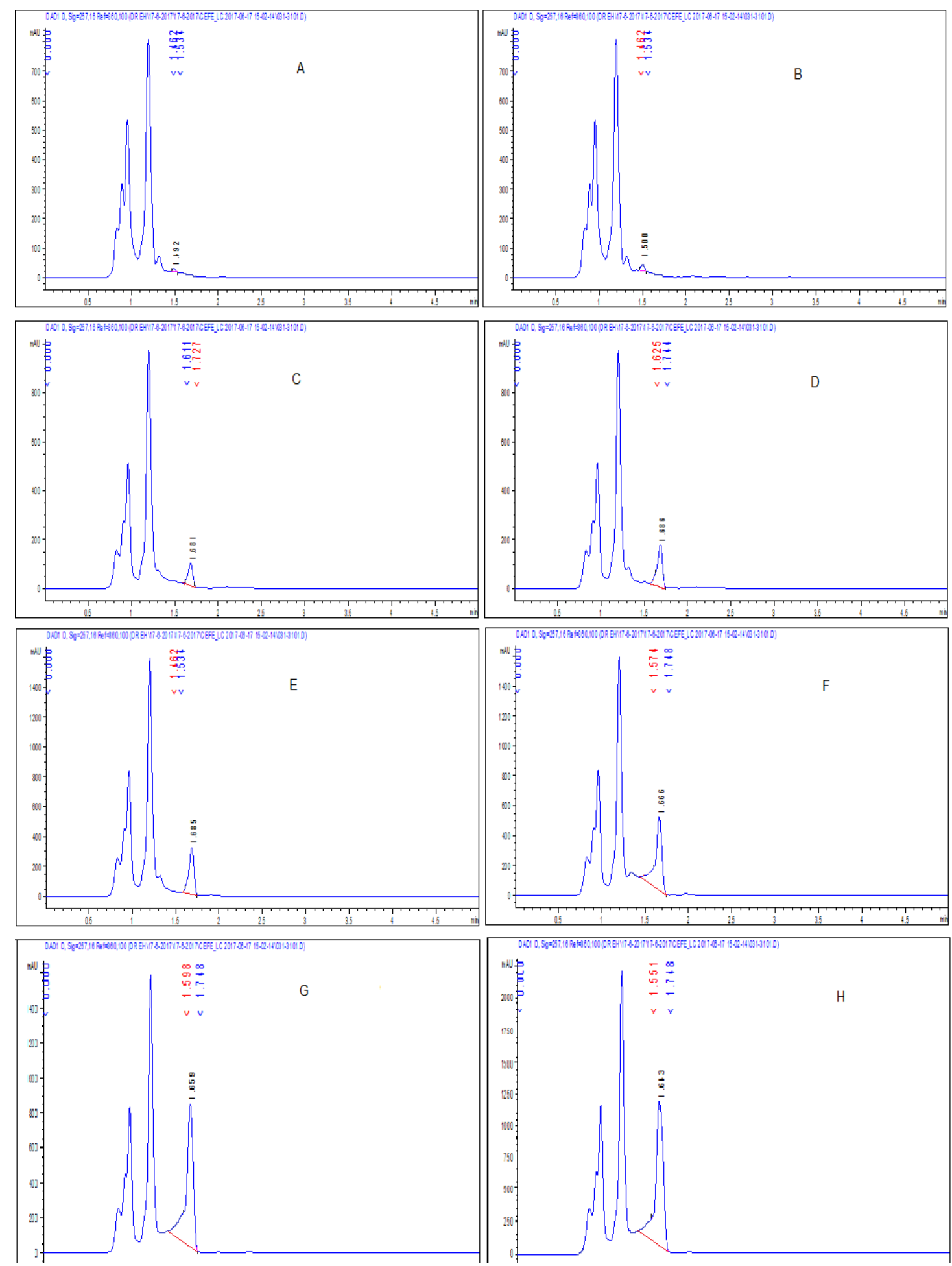

Fig. 3. HPLC chromatogram of cefepime in antibiotic free chickens spiked serum at concentrations (A) 0.18, (B) 1.0, (C) 5.0, (D) 10, (E) 25, (F) 50, (G) 75, (H) $100 \mu \mathrm{g}$. 
Comparative disposition of cefepime following single dose IV and IM administration in healthy and disease chickens is shown in the Table $3,4 \& 5$ and Fig. $4 \& 5$.

Following a single IV injection of $100 \mathrm{mg}$ cefepime $/ \mathrm{kg} \mathrm{b}$. wt. in healthy and disease chickens, Cefepime was detected in serum in a therapeutic level for 24 hours with mean values of $4.28 \pm 0.37 \mu \mathrm{g} / \mathrm{ml}$ and $2.62 \pm 0.72$ $\mu \mathrm{g} / \mathrm{ml}$ respectively (Table 5 and Fig. 4) and exceed the MIC of $S$. typhimurium which was $\leq 0.12 \mu \mathrm{g} / \mathrm{ml}$. The serum concentration-time data of cefepime (100 $\mathrm{mg} / \mathrm{kg} \mathrm{b.wt)} \mathrm{following} \mathrm{IV} \mathrm{injection} \mathrm{in}$ normal chickens was best fitted to a two compartments open model.

The pharmacokinetic parameters of cefepime after a single IV injection in healthy and diseased chickens, (Table 3 ) revealed that the distribution phase constant $(\alpha)$ was $3.26 \pm$ $0.50 \mathrm{~h}^{-1}$ and $2.47 \pm 1.03 \mathrm{~h}^{-1}$ with a distribution half-life $\left(\mathrm{t}_{1 / 2 \alpha}\right)$ of $0.217 \pm 0.036 \mathrm{~h}$. and $0.310 \pm 0.089$ h. Cefepime was transferred from central to peripheral compartment at a rate constant $\left(\mathrm{K}_{12}\right)$ at $0.922 \pm$ $0.123 \mathrm{~h}^{-1}$ and $0.664 \pm 0.342 \mathrm{~h}^{-1}$ while its passage from the peripheral to the central compartment at a rate constant $\left(\mathrm{K}_{21}\right)$ was 2.278 $\pm 0.378 \mathrm{~h}^{-1}$ and $1.74 \pm 0.69 \mathrm{~h}^{-1}$. The volume of the central compartment distribution $\left(\mathrm{V}_{1}\right)$ was $0.417 \pm 0.006$ and $0.505 \pm 0.019$ $(\mathrm{mg} / \mathrm{kg}) /(\mu \mathrm{g} / \mathrm{ml})$, whereas the volume of the peripheral compartment distribution $\left(\mathrm{V}_{2}\right)$ was $0.169 \pm 0.009$ and $0.188 \pm 0.015$ $(\mathrm{mg} / \mathrm{kg}) /(\mu \mathrm{g} / \mathrm{ml}) / \mathrm{h}$. The volume of distribution at steady state $\left(\mathrm{V}_{\mathrm{dss}}\right)$ was $0.586 \pm$ 0.11 and $0.694 \pm 0.016 \quad(\mathrm{mg} / \mathrm{kg}) /(\mu \mathrm{g} / \mathrm{ml})$. Cefepime was eliminated after IV injection with half-life $\left(\mathrm{t}_{1 / 2 \beta}\right)$ value of $4.608 \pm 0.145 \mathrm{~h}$ and $4.19 \pm 0.158 \mathrm{~h}$ and cleared by all clearance processes (CL) in the body at a rate $0.090 \pm 0.002$ and $0.118 \pm 0.002$ $(\mathrm{mg} / \mathrm{kg}) /(\mu \mathrm{g} / \mathrm{ml}) / \mathrm{h}$. The area under the serum concentration time curve ( $\mathrm{AUC}_{0-\mathrm{t}}$ ) of cefepime after IV administration was $1081.41 \pm 20.50$ and $829.91 \pm 12.68 \mu \mathrm{g} / \mathrm{ml} . \mathrm{h}$.

Table 4. Mean pharmacokinetic parameters of cefepime in healthy and Salmonella typhimurium experimentally infected chickens after single I/M injection of $100 \mathrm{mg} / \mathrm{kg}$ b. wt.

\begin{tabular}{|c|c|c|c|}
\hline \multirow{2}{*}{$\begin{array}{c}\text { Kinetic } \\
\text { parameters }\end{array}$} & \multirow{2}{*}{ Unit } & \multicolumn{2}{|c|}{ Determinants (Mean \pm S.E., n = 6) } \\
\cline { 3 - 4 } & & IM healthy Mean \pm SD & IM infected Mean \pm SD \\
\hline $\mathrm{A}$ & $\mu \mathrm{g} / \mathrm{ml}$ & $2707.10 \pm 871.36$ & $1159.90 \pm 871.21$ \\
\hline$\alpha$ & $\mathrm{h}^{-1}$ & $1.31 \pm 0.08$ & $0.915 \pm 0.366^{*}$ \\
\hline $\mathrm{B}$ & $\mu \mathrm{g} / \mathrm{ml}$ & $219.54 \pm 11.09$ & $154.31 \pm 34.58$ \\
\hline$\beta$ & $\mathrm{h}^{-1}$ & $0.189 \pm 0.006$ & $0.194 \pm 0.025$ \\
\hline $\mathrm{K}_{\mathrm{ab}}$ & $\mathrm{h}^{-1}$ & $1.42 \pm 0.077$ & $1.42 \pm 0.29$ \\
\hline $\mathrm{K}_{10}$ & $\mathrm{~h}^{-1}$ & $0.321 \pm 0.016$ & $0.295 \pm 0.046$ \\
\hline $\mathrm{k}_{12}$ & $\mathrm{~h}^{-1}$ & $0.403 \pm 0.022$ & $0.229 \pm 0.151$ \\
\hline $\mathrm{k}_{21}$ & $\mathrm{~h}^{-1}$ & $0.780 \pm 0.099$ & $0.585 \pm 0.198$ \\
\hline $\mathrm{t}_{1 / 2}$ & $\mathrm{~h}$ & $0.529 \pm 0.030$ & $0.919 \pm 0.486$ \\
\hline $\mathrm{t}_{1 / 2 \beta}$ & $\mathrm{h}$ & $3.670 \pm 0.125$ & $3.63 \pm 0.476$ \\
\hline $\mathrm{t}_{1 / 2 \mathrm{ab}}$ & $\mathrm{h}$ & $0.491 \pm 0.027$ & $0.506 \pm 0.092$ \\
\hline $\mathrm{V} / \mathrm{F}$ & $(\mathrm{mg} / \mathrm{kg}) /(\mu \mathrm{g} / \mathrm{ml})$ & $0.274 \pm 0.014$ & $0.440 \pm 0.077 * * *$ \\
\hline $\mathrm{CL}_{2} / \mathrm{F}$ & $(\mathrm{mg} / \mathrm{kg}) /(\mu \mathrm{g} / \mathrm{ml}) / \mathrm{h}$ & $0.088 \pm 0.001$ & $0.127 \pm 0.003 * * *$ \\
\hline $\mathrm{V} 2 / \mathrm{F}$ & $(\mathrm{mg} / \mathrm{kg}) /(\mu \mathrm{g} / \mathrm{ml}) / \mathrm{h}$ & $0.143 \pm 0.015$ & $0.147 \pm 0.082$ \\
\hline $\mathrm{CL}_{2} / \mathrm{F}$ & $(\mathrm{mg} / \mathrm{kg}) /(\mu \mathrm{g} / \mathrm{ml})$ & $0.110 \pm 0.004$ & $0.091 \pm 0.058$ \\
\hline $\mathrm{T}_{\max }$ & $(\mathrm{mg} / \mathrm{kg}) /(\mu \mathrm{g} / \mathrm{ml}) / \mathrm{h}$ & $1.138 \pm 0.012$ & $1.265 \pm 0.013 * * *$ \\
\hline $\mathrm{C}_{\max }$ & $\mathrm{h}$ & $193.06 \pm 2.27$ & $132.93 \pm 1.53 * * *$ \\
\hline
\end{tabular}




\begin{tabular}{|c|c|c|c|}
\hline AUC $_{0-\mathrm{t}}$ & $\mu \mathrm{g} / \mathrm{ml}$ & $1127.58 \pm 14.48$ & $781.20 \pm 16.25 * * *$ \\
\hline $\mathrm{AUC}_{0 \text {-inf }}$ & $\mu \mathrm{g} / \mathrm{ml} \mathrm{h}$ & $1140.10 \pm 15.78$ & $789.49 \pm 18.84 * * *$ \\
\hline $\mathrm{AUMC}$ & $\mu \mathrm{g} / \mathrm{ml} . \mathrm{h}$ & $6232.71 \pm 198.27$ & $4236.91 \pm 331.32 * * *$ \\
\hline $\mathrm{MRT}$ & $\mathrm{h}$ & $5.466 \pm 0.106$ & $5.36 \pm 0.319$ \\
\hline $\mathrm{F}$ & $\%$ & $104.30 \pm 2.34$ & $94.15 \pm 2.71 * * *$ \\
\hline
\end{tabular}

a Kinetic parameter as described by Zhang et al., 2010. A, zero-time intercept of the distribution slope. $\mathrm{B}$, zero-time intercept of decline in serum concentration of drug. $\alpha$, distribution rate constant. $\beta$, elimination rate constant. $\mathrm{K}_{\mathrm{ab}}$ Absorption rate constant, $\mathrm{k}_{10}$, first-order elimination rate constant from central compartment. $\mathrm{k}_{12}$, rate constant for passage from central to peripheral compartment. $\mathrm{k}_{21}$, rate constant for passage from peripheral to central compartment. $t_{1 / 2 \alpha}$, the distribution half-life. $t_{1 / 2 \beta}$, elimination half-life. $t_{1 / 2 a b}$, absorption half-life. $T_{\max }$, the time at which the maximum concentration of drug was reached after extra vascular administration (h). $\mathrm{C}_{\text {max }}$, maximum serum concentration of drug in blood after extravascular administration $(\mu \mathrm{g} / \mathrm{ml}) . \mathrm{AUC}_{0-\mathrm{t}}$, area under the [plasma drug concentration versus time] curve.AUC ${ }_{0-\infty}$, total area under the concentration-time curve from zero to infinity. AUMC, area under the first moment curve.MRT, mean residence time, F \%, bioavailability.

Significant at $* \mathrm{P} \leq 0.05 * * \mathrm{P} \leq 0.01 * * * \mathrm{P} \leq 0.001$ when compared with respective values of cefepime (IM) healthy and disease chickens.

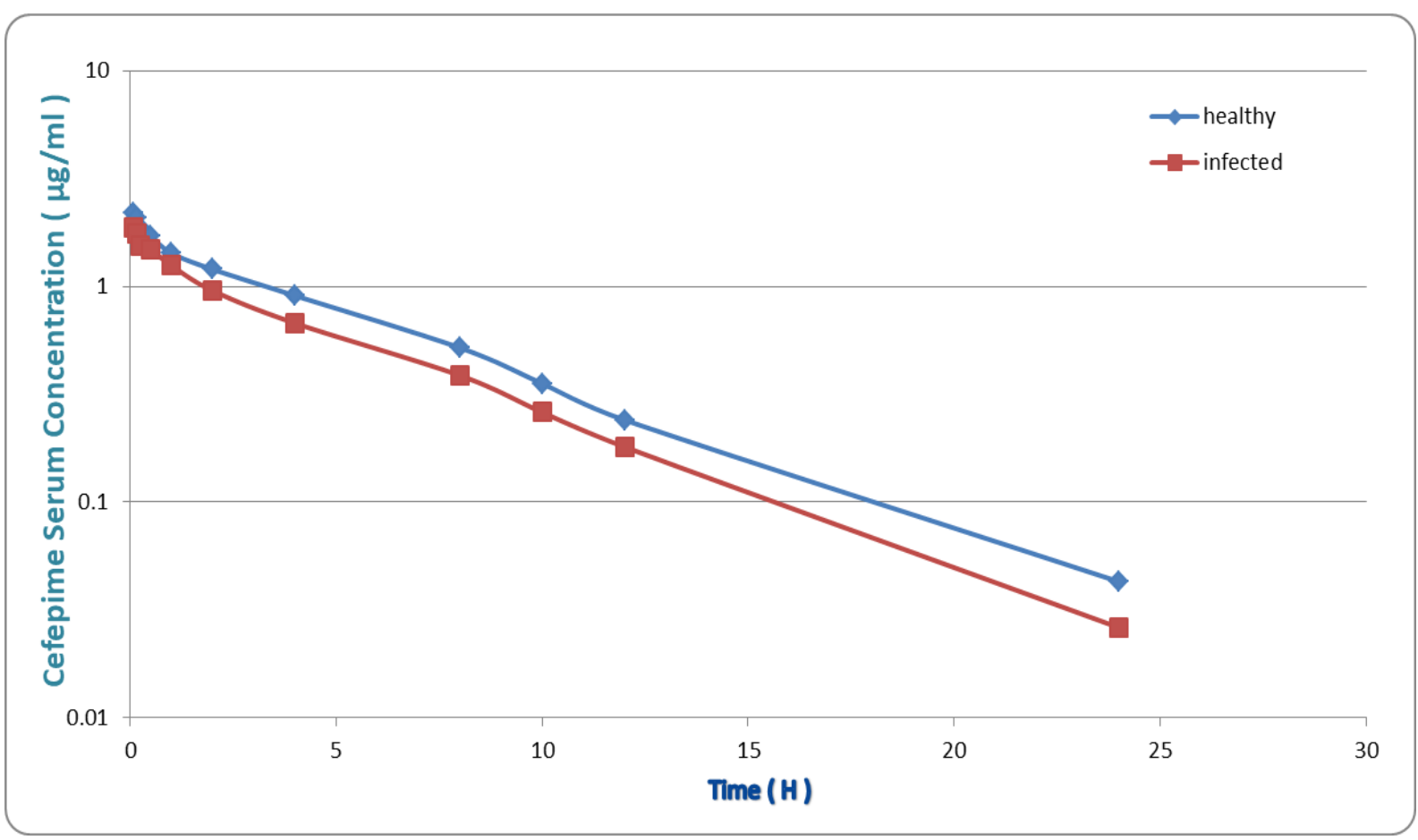

Fig. 4. Semi logarithmic graph depicting the time-concentration of cefepime in serum of healthy and Salmonella typhimurium infected chickens after single intravenous injection of $100 \mathrm{mg} / \mathrm{kg} \mathrm{b.wt}$.

Following a single IM administration of cefepime (100 mg / $\mathrm{kg}$ b.wt.), the drug reached its maximum serum concentrations $\left(\mathrm{C}_{\max }\right) \quad 193.06 \pm 2.27 \mu \mathrm{g} / \mathrm{ml}$ after $1.138 \pm 0.012 \mathrm{~h}$ post administration
$\left(\mathrm{T}_{\max }\right)$ in healthy chickens while in diseased chickens the $\left(\mathrm{C}_{\max }\right)$ was $132.93 \pm 1.53 \mu \mathrm{g} / \mathrm{ml}$ after $1.265 \pm 0.013 \mathrm{~h}$ post administration $\left(\mathrm{T}_{\max }\right)$. Cefepime was detected in serum in a therapeutic level for 
24 hours with mean value $2.28 \pm 0.32$ in healthy chickens, $1.32 \pm 0.30$ in diseased chickens (Table $4 \& 5$ and Fig. 5) and exceed the MIC of $S$. typhimurium which was $\leq 0.12 \mu \mathrm{g} / \mathrm{ml}$. The serum concentrationtime data of cefepime $(100 \mathrm{mg} / \mathrm{kg} \mathrm{b.wt})$ following IM injection in normal chickens was best fitted to a two compartments open model. The pharmacokinetic parameters following a single IM administration of cefepime were recorded in table 4 .

The obtained results revealed that the absorption rate constant $\left(\mathrm{K}_{\mathrm{ab}}\right)$ was 1.42 $\pm 0.077 \mathrm{~h}^{-1}$ in healthy chickens while in diseased chickens was $1.42 \pm 0.29 \mathrm{~h}^{-1}$ while absorption half-life $\left(\mathrm{t}_{1 / 2 \mathrm{ab}}\right)$ was $0.491 \pm$ $0.027 \mathrm{~h}$ in healthy chickens, in diseased chickens absorption half-life $\left(\mathrm{t}_{1 / 2 \mathrm{ab}}\right)$ was 0.506 $\pm 0.092 \mathrm{~h}$. Cefepime reached its maximum concentrations $\left(\mathrm{C}_{\max }\right) 193.06 \pm 2.27 \mu \mathrm{g} / \mathrm{ml}$ after maximum time equal to $\left(\mathrm{T}_{\max }\right) 1.138 \pm$ $0.012 \mathrm{~h}$ in healthy chickens, in diseased chickens the maximum concentrations $\left(\mathrm{C}_{\max }\right)$ of $132.93 \pm 1.53 \mu \mathrm{g} / \mathrm{ml}$ at maximum time equal to $\left(\mathrm{T}_{\max }\right) 1.265 \pm 0.013 \mathrm{~h}$. Cefepime was eliminated at a rate $\left(\mathrm{K}_{10}\right)$ equal to 0.321 $\pm 0.016 \mathrm{~h}$. The elimination half-life $\left(\mathrm{t}_{1 / 2 \beta}\right)$ was $3.670 \pm 0.125 \mathrm{~h}$ in healthy chickens, while in diseased chickens the eliminated at a rate $\left(\mathrm{K}_{10}\right)$ was $0.295 \pm 0.046 \mathrm{~h}$ and the elimination half-life $\mathrm{t}_{1 / 2 \beta}$ was $3.63 \pm 0.476 \mathrm{~h}$. Cefepime was cleared by all clearance processes $(\mathrm{Cl} / \mathrm{F})$ in the body at rate of 0.088 $\pm 0.001(\mathrm{mg} / \mathrm{kg}) /(\mu \mathrm{g} / \mathrm{ml}) / \mathrm{h}$. The area under serum concentration time curve of cefepime after a single IM administration (AUC $0-\mathrm{t}$ ) was $1127.58 \pm 14.48 \mu \mathrm{g} / \mathrm{ml}$.h in healthy chickens. In diseased chickens, cefepime was cleared by all clearance processes (CL/F) in the body was $0.127 \pm 0.003(\mathrm{mg} / \mathrm{kg})$ $/(\mu \mathrm{g} / \mathrm{ml}) / \mathrm{h}$. The area under serum concentration time curve of cefepime after a single IM administration $\left(\mathrm{AUC}_{0-\mathrm{t}}\right)$ was $781.20 \pm 16.25 \mu \mathrm{g} / \mathrm{ml}$.

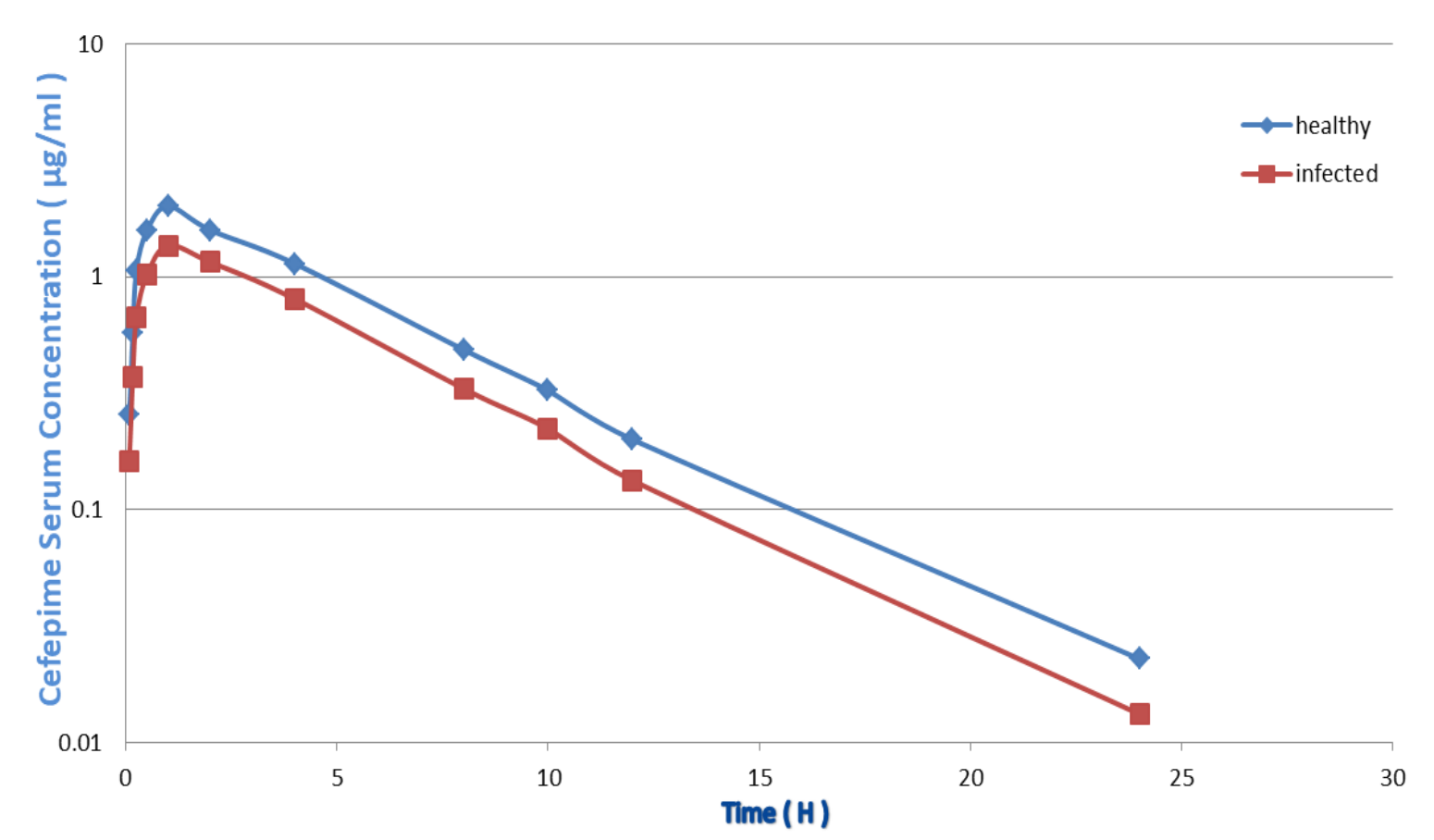

Fig. 5. Semi logarithmic graph depicting the time-concentration of cefepime in serum of healthy and Salmonella typhimurium infected chickens after single intamuscular injection of $100 \mathrm{mg} / \mathrm{kg} \mathrm{b}$.wt. 
Comparison between serum

concentration of cefepime in normal and

Salmonella typhimurium infected chickens following IV and IM injection:
After IV and IM administration there was a significant $(\mathrm{P} \leq 0.001)$ decrease in serum concentration of cefepime in $S$. typhimurium infected chickens as compared to healthy ones (Table 5).

Table 5. Serum concentration $(\mu \mathrm{g} / \mathrm{ml})$ of cefepime in healthy and $S$. typhimurium infected chickens after single intravenous and intramuscular injection of $100 \mathrm{mg} / \mathrm{kg} \mathrm{b} . \mathrm{wt} .(\mathrm{n}=6)$.

\begin{tabular}{|c|c|c|c|c|}
\hline \multicolumn{5}{|c|}{ Mean serum cefepime concentration $( \pm$ SD) } \\
\hline \multirow{2}{*}{ Time (h) } & \multicolumn{2}{|c|}{ Single IV injection } & \multicolumn{2}{|c|}{ Single IM injection } \\
\hline & $\begin{array}{l}\text { Apparently } \\
\text { healthy }\end{array}$ & S. typhimurium infected & $\begin{array}{l}\text { Apparently } \\
\text { healthy }\end{array}$ & S. typhimurium infected \\
\hline 0.083 & $220.10 \pm 1.97$ & $187.26 \pm 2.05 * * *$ & $25.57 \pm 0.80$ & $16.06 \pm 1.06 * * *$ \\
\hline 0.166 & $206.78 \pm 2.83$ & $175.73 \pm 1.43 * * *$ & $57.23 \pm 2.40$ & $37.07 \pm 1.87 * * *$ \\
\hline 0.25 & $186.61 \pm 2.60$ & $155.39 \pm 1.44 * * *$ & $106.49 \pm 1.06$ & $66.87 \pm 2.08 * * *$ \\
\hline 0.50 & $170.94 \pm 1.69$ & $147.76 \pm 2.72 * * *$ & $157.39 \pm 2.27$ & $101.95 \pm 2.33 * * *$ \\
\hline 1.00 & $142.61 \pm 1.64$ & $124.95 \pm 1.33 * * *$ & $200.58 \pm 3.89$ & $135.93 \pm 2.62 * * *$ \\
\hline 2.00 & $120.07 \pm 2.06$ & $95.54 \pm 2.46 * * *$ & $158.56 \pm 1.08$ & $115.59 \pm 1.85^{* * *}$ \\
\hline 4.00 & $90.67 \pm 3.50$ & $67.56 \pm 1.12 * * *$ & $113.71 \pm 1.87$ & $80.27 \pm 3.41 * * *$ \\
\hline 8.00 & $51.97 \pm 2.55$ & $38.67 \pm 1.49 * * *$ & $48.54 \pm 1.57$ & $33.01 \pm 1.48 * * *$ \\
\hline 10.00 & $35.49 \pm 1.45$ & $26.10 \pm 1.71 * * *$ & $32.42 \pm 3.02$ & $22.24 \pm 2.48 * * *$ \\
\hline 12.00 & $24.04 \pm 1.75$ & $18.03 \pm 1.56 * * *$ & $19.97 \pm 1.50$ & $13.31 \pm 1.86^{* * *}$ \\
\hline 24.00 & $4.28 \pm 0.37$ & $2.62 \pm 0.72 * * *$ & $2.28 \pm 0.32$ & $1.32 \pm 0.30 * * *$ \\
\hline
\end{tabular}

$* \mathrm{P} \leq 0.05 \quad * * \mathrm{P} \leq 0.01 \quad * * * \mathrm{P} \leq 0.001$

\section{Discussion}

Cefepime is a parenteral fourth generation cephalosporin antibiotic with an extended spectrum of antimicrobial activity. It is active against many Gram-positive and Gram-negative bacteria, including most members of the family Enterobacteriaceae, Pseudomonas aeruginosa, and Staphylococcus aureus (Chong et al.,1993) with reduced susceptibility to extendedspectrum $\beta$-lactamases (Jacoby and Cerreras, 1990).

In the present investigation, the drug disposition after i.v and i.m administration of $(100 \mathrm{mg} / \mathrm{kg})$ in chickens was best fitted by a two-compartment open model. The two-compartments open model was reported to be the best to describe the disposition of cefepime sheep following i.v administration of $20 \mathrm{mg} / \mathrm{kg}$ (Patel et al., 2010), goats following i.v administration of $10 \mathrm{mg} / \mathrm{kg}$ and co-administration with flunixin (El-Hewaity، 2014). However, the non-compartmental analysis was used for cefepime disposition in ewes after i.m injection of $20 \mathrm{mg} / \mathrm{kg}$ (Ismail, 2005a), rabbits after i.m injection (Goudah et al., 2006) and i.v injection (Abd El-Aty et al., 2007, Rule et al., 2010). Moreover, the serum concentration of cefepime was fitted to one-compartment open model in buffalo calves following IM administration of 10 
$\mathrm{mg} / \mathrm{kg}$ (Joshi and Sharma، 2007), goats after IV and IM administration of $10 \mathrm{mg} / \mathrm{kg}$ (Prawez et al., 2010).

Following a single IV administration, the half-life of distribution $\left(\mathrm{t}_{1 / 2 \alpha}\right)$ was very short $(0.217 \pm 0.036 \mathrm{~h})$ in healthy broiler chickens injected with cefepime in a single dose of $100 \mathrm{mg} / \mathrm{kg}$. The distribution half-life is closely similar to cefepime that previously reported in goats $(0.20 \pm 0.004 \mathrm{~h}$, ElHewaity، 2014), buffalo calves (0.18 \pm 0.05 h, Joshi and Sharma، 2007), sheep (0.2 \pm 0.02 h, Patel et al. 2010), calves $(0.2 \pm 0.02$ h; $0.25 \pm 0.07$ h, Ismail, 2005b; Pawar and Sharma، 2008) and ewes $(0.18 \pm 0.008 \mathrm{~h}$, Ismail, 2005a). Longer half-life of distribution was recorded for cefepime in bull camels $(0.30 \pm 0.05 \mathrm{~h}$, Goudah et al., 2009), and neonatal foals and adult dogs $(0.30 \pm 0.16 \mathrm{~h} ; 0.39 \pm 0.21 \mathrm{~h}$, Gardner and Papich, 2001) respectively.

In this study, the results showed that cefepime serum concentration $(\mu \mathrm{g} / \mathrm{ml})$ after single IV injections into Salmonella typhimurium infected chickens were generally lower than that in healthy ones. This indicates that cefepime disappeared more rapidly from blood of diseased than healthy chickens. This is confirmed by the rapid transfer of the drug from the central to the peripheral compartment in diseased than in normal chickens $\left(\mathrm{K}_{12}, 0.664 \pm 0.342 \mathrm{~h}^{-1}\right)$ in diseased vs $\left(0.922 \pm 0.123 \mathrm{~h}^{-1}\right)$ in healthy. The most likely explanation of the decreased serum concentration is the wide distribution of the drug in the body of diseased than in healthy chickens. This suggestion is confirmed by the larger volume of distribution $\left(\mathrm{V}_{\mathrm{dss}}\right)$ of cefepime in diseased $(0.694 \pm 0.016)$ than in healthy chickens $(0.586 \pm 0.11 \mathrm{mg} / \mathrm{kg}(\mu \mathrm{g} / \mathrm{ml})$. Moreover, the cefepime is rapidly eliminated from the body of diseased than normal chickens $(\mathrm{Cl}, 0.118 \pm 0.002)$ in diseased vs $(0.090 \pm 0.002$ $(\mathrm{mg} / \mathrm{kg}) /(\mu \mathrm{g} / \mathrm{ml}) / \mathrm{h}$ in healthy could be another factor for the observed lower serum concentration of cefepime in serum of diseased chickens. This is also confirmed by the short elimination half-life $\left(\mathrm{t}_{1 / 2 \beta}\right)$ in diseased $(4.19 \pm 0.158 \mathrm{~h})$ than that in the healthy birds $(4.608 \pm 0.145 \mathrm{~h})$.

The lower blood concentration, wide distribution and rapid disappearance of cefepime from the serum after single IV injections into Salmonella typhimurium infected chickens than those in normal chickens could be attributed to the higher penetrating power of cefepime to the inflamed tissues. From the previous discussion it could be suggested that cefepime is widely distributed and rapidly eliminated in diseased birds than in healthy ones.

The volume of distribution $\left(\mathrm{V}_{\mathrm{dss}}\right)$ was closely related to cefepime that previously reported in goats $(0.44 \pm 0.01 \mathrm{mg} / \mathrm{kg}$, ElHewaity, 2014) calves $(0.42 \pm 0.08 ; 0.43 \pm$ $0.03 ; 0.52 \pm 0.03 \mathrm{mg} / \mathrm{kg}$, Joshi and Sharma, 2007, Patel et al., 2006, Patil et al., 2012) respectively, but higher than that reported in bull camels $(0.10 \pm 0.04 \mathrm{mg} / \mathrm{kg}$, Goudah et al., 2009), calves $(0.21 \pm 0.01 \mathrm{mg} / \mathrm{kg}$, Ismail, 2005b), ewes $(0.32 \pm 0.01 \mathrm{mg} / \mathrm{kg}$, Ismail, 2005a) and neonatal foals and adult $\operatorname{dogs}(0.18 \pm 0.05 ; 0.14 \pm 0.04 \mathrm{mg} / \mathrm{kg}$, Gardner and Papich, 2001) respectively.

The total body clearance (CL) of cefepime following a single IV administration in the present study was $(0.090 \pm$ $0.002(\mathrm{mg} / \mathrm{kg}) /(\mu \mathrm{g} / \mathrm{ml}) / \mathrm{h})$, this obtained result was agreed with cefepime that previously reported in goats $(0.098 \pm$ $0.0004 \mathrm{mg} / \mathrm{kg} / \mathrm{h}, \quad$ (El-Hewaity, 2014), neonatal foals and adult dogs $(0.08 \pm 0.02$; $0.13 \pm 0.04 \mathrm{mg} / \mathrm{kg} / \mathrm{h}$, (Gardner and Papich, 2001) respectively, but disagreed with those reported for Cefepime in calves $(86.1 \pm$ $3.65 ; 1.81 \pm 0.16 ; 1.1 \pm 0.08 \mathrm{mg} / \mathrm{kg} / \mathrm{h}$, Joshi and Sharma, 2007, Patel et al., 2006, Ismail, $2005 \mathrm{~b})$, goats $(1.1 \pm 0.54 \mathrm{mg} / \mathrm{kg} / \mathrm{h}$, Prawez et al., 2010) respectively, bull camels (0.04 $\pm 0.01 \mathrm{mg} / \mathrm{kg} / \mathrm{h}$, Goudah et al., 2009) and sheep (2.48 \pm 0.09, Patel et al., 2010). 
The elimination half-life $\left(t_{1} / 2 \beta\right)$ of cefepime following a single i.v administration (4.6 \pm $0.15 \mathrm{~h})$ was agreed with that reported in goats (3.34 $\pm 0.12 \mathrm{~h}$, El-Hewaity, 2014), calves (3.7 $\pm 0.16 \mathrm{~h}$, Patel et al., 2006) but disagreed with those reported in calves $(2.67$ $\pm 0.29 ; 2.38 \pm 0.16 \mathrm{~h}$, Joshi and Sharma, 2007, Ismail, 2005b) respectively, bull camels (2.0 $\pm 0.23 \mathrm{~h}$, Goudah et al., 2009), goats (1.86 $\pm 0.54 \mathrm{~h}$, Prawez et al., 2010) respectively, sheep $(2.54 \pm 0.12 \mathrm{~h}$, Patel et al., 2010), ewes $(1.76 \pm 0.07 \mathrm{~h}$, Ismail, 2005a), rabbits (2.94 $\pm 0.16 \mathrm{~h}$, Abd El-Aty et al., 2007) and neonatal foals and adult dogs $(1.65 \pm 0.10 \mathrm{~h} ; 1.09 \pm 0.27 \mathrm{~h}$, Gardner and Papich, 2001) respectively.

Following a single IM administration, cefepime was rapidly and efficiently absorbed in chickens. The reported half-life of absorption ( $\left.\mathrm{t}_{1 / 2 \mathrm{ab}}\right)$ was $(0.49 \pm 0.03 \mathrm{~h})$ which similar to that recorded in cefepime in ewes $(0.49 \pm 0.05 \mathrm{~h}$, Ismail 2005 a). However, it was disagreed with cefepime that previously reported in goats $(0.77 \pm 0.34 ; 0.25 \pm 0.02$; h, Prawez et al., 2010, El-Hewaity, 2014) respectively, bull camels (2.5 $\pm 0.27 \mathrm{~h}$, Goudah et al., 2009) and calves $(0.29 \pm 0.02 ; 0.17 \pm 0.01 \mathrm{~h}$, Ismail 2005b, Patel et al., 2012) respectively. Although there was no significant difference in the absorption halflife between diseased and healthy chickens, the serum concentration in diseased chickens was generally lower than healthy ones. Once again, this is due to rapid disappearance of cefepime from the central to the peripheral compartment as confirmed by short $\mathrm{K}_{12}$ in diseased $\left(0.229 \pm 0.151 \mathrm{~h}^{-1}\right)$ than normal chickens $\left(0.403 \pm 0.022 \mathrm{~h}^{-1}\right)$. Cefepime reached to a maximum serum concentration $\left(\mathrm{T}_{\max }\right)$ after $(1.14 \pm 0.01 \mathrm{~h})$ which nearly similar to cefepime that previously reported in calves $(1.1 \pm 0.08 \mathrm{~h}$, Ismail, 2005b), goats $(0.91 \pm 0.08 \mathrm{~h}$, ElHewaity, 2014) and ewes (1.1 $\pm 0.2 \mathrm{~h}$, Ismail, 2005a) but disagreed with those reported in calves $(0.75 \mathrm{~h} ; 0.75 \mathrm{~h}$, Joshi and
Sharma, 2007, Patel et al., 2013) respectively, goats $(0.80 \pm 0.11 \mathrm{~h}$; Prawez et al., 2010), rabbits $(0.5 \mathrm{~h}$, Goudah et al., 2006) and sheep (0.75 h, Patel et al., 2010). The mean peak serum concentration of cefepime $\left(C_{\max }\right)$ was $(193.06 \pm 2.27 \mu \mathrm{g} / \mathrm{ml})$ after i.m administration of $100 \mathrm{mg} / \mathrm{kg} . \mathrm{bw}$. These values were much higher than those recorded in goats $(49.32 \pm 10.33 ; 16.49 \pm 0.53$ $\mu \mathrm{g} / \mathrm{ml}$, Prawez et al., 2010, El-Hewaity 2014) respectively, calves (30.2 \pm 0.09 ; $21.7 \pm 1.1 \mu \mathrm{g} / \mathrm{ml}$, Joshi and Sharma, 2007, Ismail, 2005b) respectively, sheep (26.34 \pm $1.44 \mu \mathrm{g} / \mathrm{ml}$, Patel et al., 2010), rabbits $(114.93 \pm 9.51 \mu \mathrm{g} / \mathrm{ml}$, Goudah et al., 2006). Variation in species as well as doses could be considered the causes of these variations. The bioavailability (F\%) of cefepime in normal chickens were $104.30 \pm 2.34$ and $94.15 \pm 2.71$ in diseased chickens (which was agreed with those reported in cefquinome in yellow cattle $(104 \pm 7.13 \%$, Shan et al., 2013) and sheep (103 $\pm 8 \%$, and 107.11 \pm 4.66, Patel et al., 2010 and Nimesh et al., 2012) but higher than that reported in cefepime in goats $(86.45 \pm 17.39 ; 92.66 \%$, Prawez et al., 2010 and El-Hewaity, 2014) respectively, calves $\quad(95.3 \pm 10.5$; 95.7 $\pm 7.44 \%$, Joshi and Sharma, 2007 and Ismail, 2005b) respectively, and ewes (86.8 $\pm 7.5 \%$, Ismail 2005a).

The AUC reported in this study was $(1127.58 \pm 14.48 \mu \mathrm{g} / \mathrm{ml} . \mathrm{h})$ which higher than that reported in goats $(156.98 \pm 44.5$; $94.87 \pm 3.89 \mu \mathrm{g} / \mathrm{ml}$.h, Prawez et al., 2010, El-Hewaity, 2014) respectively, calves $(110.3 \pm 7.88 ; 90.45 \pm 8.7 \mu \mathrm{g} / \mathrm{ml} . \mathrm{h}$, Joshi and Sharma, 2007, Ismail, 2005b) respectively, sheep $(140.9 \pm 8.67 \mu \mathrm{g} / \mathrm{ml} . \mathrm{h}$, Patel et al.,2010), adult dogs $(114.8 \pm 36.62 \mu \mathrm{g} / \mathrm{ml} . \mathrm{h}$, Gardner and Papich, 2001) respectively and ewes (121.4 $\pm 9.7 \mu \mathrm{g} / \mathrm{ml} . \mathrm{h}$, Ismail, 2005a), Ceftiofur in chickens $(345.17 \pm 6.62$ $\mu \mathrm{g} / \mathrm{ml} . \mathrm{h}$, (El-Sayed et al., 2015b), Cefquinome in broiler chickens $(48.79 \pm 1.24 \mu \mathrm{g} / \mathrm{ml} . \mathrm{h}, \quad$ El-Sayed et al., 2015a). 
These differences reflect the difference in the AUC reported in this study. This differences in the AUC is probably because of the differences in the doses used which are consequently reflects the difference in the $\mathrm{F} \%$.

\section{Conclusion:}

From the present study it could be concluded that, the IM bioavailability of cefepime is excellent and this value revealed a better absorption from its site of IM administration. The serum concentration of cefepime in normal and $S$. typhimurium experimentally infected chickens following IV and IM administration could be detected till 24 hours and remaining above MIC for Salmonella typhimurium $(\leq 0.12 \mu \mathrm{g} / \mathrm{ml})$, this indicate that cefepime is the drug of choice for treatment of Salmonella typhimurium infection in broiler chickens.

\section{References}

Abd El-Aty AM, Goudah A, Mouneir, SM, Sunwoo YE, Jang JH, Shin JG, Shim JH and Shimoda M (2007): AcutePhase response alters the disposition kinetics of cefepime following intravenous administration to rabbit. Veterinary Communications, 31:67-75.

Berly DA, Lindgren BW (1990). Statistics: Theory and Methods Brooks 1 cole publishing company, Pacific Grove California.

Chong Y, Lee K, Kwon OH (1993). InVitro Activities of cefepime against enterobacter cloacae, serratia marcescens, pseudomonas aeruginosa and other aerobic gram-negative bacilli. Journal of Antimicrobial Chemotherapy, 32: 21-29.
Del RPM, Vellone P, Fragapane M, di M, Mazzitelli R (2008). Cefepime for prophylaxis of infections in the surgery of cholelithiasis. Results of a multicentric comparative trial. Acta Bio- medica, 79: 23-27.

Dog An, A, Nemutlu E, Aykut OZM, ErogLH, Sedef K, Beksac SM (2013). The pharmacokinetic profiles of preoperative prophylactic cefepime application in pregnant and nonpregnant women undergoing surgical interventions using a fully validated liquid chromatographic method. Chromatographia, 76: 1513-1519.

El-Hewaity M (2014). Influence of flunixin on the disposition kinetic of cefepime in goats. Advances in Pharmacological Sciences, Article ID 471517.

El- Rabbat AN, Abdel-wadood MH, Sayed M,Mousa SH (2010).High performance Liquid chromatographic determination and Pharmacokinetic study of cefepime in goat plasma and milk after precolumn derivatization with $\mathrm{Hg}(1)$. Journal of Separation Science, 33: 2599-2609.

El-Sayed MG, El-Komy AA, Mobarez EA, El-Mahdy AM (2015a). Pharmacokinetics and Tissue residues of cefquinome in normal and salmonella entretidis infected chickens. World Journal of Pharmacy and Pharmaceutical Sciences, 10(4): 1974-1987.

El-Sayed, MGA, El-Komy AAA, El barawy AM, Ibrahim DMA (2015b). Pharmacokinetics and tissue residues of ceftiofur in normal and Escherichia coli infected chickens. Journal of Physiology and Pharmacology Advances, 5(3): 574-582.

Endimiani A, F Perez F, Bonomo RA (2008). Cefepime: a reappraisal in an era of increasing antimicrobial 
resistanc. Expert Review of antiinfective therapy, 6(6): 805-824.

Feizi A, Etekali H, Amoughli TB, Khayat NMH (2009). The effect of cefepime injection on clinical finding, gross lesion and some biochemical parameters in rose ringed parakeet. Veterinary clinical pathology, 3(10): 459 - 464.

Forgue ST, Shyu WC, Gleason CR, Pittman KA, Barbhaiya RH (1987). Pharmacokinetics of the novel cephalosporin cefepime (BMY28142) in rats and monkeys. Antimicrobe Agents Chemother, 31:799-804.

Gardner SY, Papich MG (2001). Comparison of cefepime pharmacokinetics in neonatal foals and adult dogs. Journal Veterinary Pharmacology and Therapeutics, 24: 187-192.

Goudah A, Mouneir SM, Shim JH and Abd El-Aty AM (2006). Influence of Endotoxin induced fever on the pharmacokinetics of intramuscularly administered cefepime in rabbits. Journal of Veterinary Science, 7: 151-155.

Goudah A, Shin HC, Kim JS, Chang BJ, Shim JH and Abd El-Aty AM (2009). Evaluation of single-dose pharmacokinetics of cefepime in healthy bull camels (Camelus dromedaries). Journal of Veterinary Pharmacology and Therapeutics, 32: 393-396.

Guglick MA, Macallister CG, Clarke CR, Pollet R, Hague C, Clarke JM (1998). Pharmacokinetics of cefepime and comparison with those of ceftiofur in horses. American Journal of veterinary Research, 59: Ismail MM (2005a). Pharmacokinetics of Cefepime administered by I.V. and I.M. routes to ewes. Journal of Veterinary
Pharmacology and Therapeutics, 28: 499-503.

Ismail MM (2005b). Disposition kinetics, Bioavailability and renal clearance of cefepime in calves. Veterinary Research Communications, 29: 6979.

Jacoby GA, Carreras I (1990). Activities of Beta-Lactam Antibiotics against Escherichia Coli strains producing extended-spectrum Beta-Lactamases. Antimicrobial Agents and Chemotherapy, 34: 858-862.

Jime'nezPalacios FJ, Callejo'n Mocho'n M, Jime'nez Sa'nchez JC, Bello Lo'pez MA, Guira'um Pe'rez A (2005). Validation of an HPLC Method for Determination of Cefepime (a Fourth-Generation Cephalosporin). Determination in Human Serum, Cerebrospinal Fluid, and Urine. Pharmacokinetic Profiles. Chromatographia, 62 (7/8): 355-361.

Joshi B, Sharma SK (2007). Pharmacokinetic Disposition and Bioavailability of cefepime in buffalo calves. Journal of Veterinary Pharmacology and Therapeutics, 30: 500-502.

Joshi B, Sharma SK (2009). The pharmacokinetics of cefepime in E. coli lipopolysaccharide induced febrile buffalo calves. Veterinarski arhive, 79: 523-530.

Klesel N, Seeger K (1983). Pharmacokinetic properties of the new cephalosporin antibiotic HR 810 in animals. Infection, 11:318-321.

Nimesh NP, Hiren BP, Shital DP, Jatin HP, Shailesh KB, Aswin MT (2012). Effect of ketoprofen coadministration or febrile state on ffect of ketoprofen co-administration or febrile state on pharmacokinetic of cefepime in sheep harmacokinetic of cefepime in sheep. Veterinarski Arhiv, 82 (5): 473-481. 
Ozbek B, Otuk G (2010). Activities of fourth generation cephalosporins alone and in combination with gentamicin, amikacin, ciprofloxacin and levofloxacin against bloodstream Pseudomonas aeruginosa isolates. Indian Journal of MedicalMicrobiology, 28 : 84-85.

Patel UD, Bhavsar S, Thaker AM (2006). Pharmacokinetics and dosage regimen of cefepime following single dose intravenous administration in calves. Iranian Journal of Pharmacology \& Therapeutics, 5: 127-130.

Patel PN, Patel UD, Bhavsar ShK, Thaker AM (2010). Pharmacokinetics of cefepime following intravenous and intramuscular administration in sheep. Iranian Journal of Pharmacology \& Therapeutics, 9: 710.

Patel RB, Bhavsar ShK, Solanki PF, Patel JH, Varia RD, Modi Falguni D, patel MD (2013). Pharmacokinetics of cefepirome following intravenous and intramuscular administration in cow calves. Science international. 1:371374.

Patil AJ, Bhavsar SK, Patel HB, Patel NN, Patel SD, Dewda S, Patel JH, Thaker AM (2012). Effect of ketoprofen coadministration on pharmacokinetic of cefepime in cow calves. International Journal of Veterinary Science, 1(2): $72-75$.

Pawar YG, Sharma SK (2008). Influence of E. coli lipopolysaccharide induced fever on the plasma kinetics of cefepime in cross-bred calves. Veterinary Research Communication, 32: 123-130.
Prawez S, Raina R, Dimitrova D, Pankaj $\mathrm{KN}$, Ahanger A, Pawan A,Verma k (2010). The Pharmacokinetics of cefepime in goats following singledose i.v. and i.m. administration. Turkish Journal of Veterinary and Animal Sciences, 34(5): 427-431.

Riviere JE, Papich MG (2009). $\beta$ Lactam Antibiotics: Penicillins, Cephalosporins and Related Drugs.Veterinary Pharmacology and Therapeutics, 9th Edn., John Wiley and Sons, USA., ISBN: 978-0-8138-2061-3, pp: 866-887.

Rule R, Vita M, Martino P (2010). Kinetics and Penetration into inflammatory tissue cage fluid of cefepime administered to rabbits. Scandinavian Journal of Laboratory Animal Science, 37(1): 23-26.

Ryan JA, Scott N, Michael HK (2013). Salmonella enterica Typhimurium infection causes metabolic changes in chicken muscle involving AMPK, fatty acid and insulin/mTOR signaling. Veterinary Research, 44: 35.

Sultana N, Arayne MS (2007). In vitro activity of cefadroxil,cephalexin, cefatrizine and cefpirome in presence of essential and trace elements. Pakistan Journal of Pharmaceutical Sciences, 20: 305310.

Wendy I M, Wayne LB, Alan JH (1998). Evaluation of the Efficacy of Intraperitoneal Immunization in Reducing Salmonella Typhimurium Infection in Chickens. Poultry Science, 77: 1874-1883.

Zhang Y, Meirong H, Jianping Z, Shaofei $X$ (2010). KSolver: An add-in program for pharmacokinetic and 
pharmacodynamic data analysis in Microsoft Excel. Computer methods and programs in biomedicine, 99(3):

306-14 . 